\title{
Multi-criteria modelling of drought: a study of Brandenburg Federal State, Germany
}

\author{
Christopher Ihinegbu ${ }^{1,2,3} \cdot$ Taiwo Ogunwumi ${ }^{1,2}$ (B)
}

Received: 11 April 2021 / Accepted: 21 May 2021 / Published online: 13 June 2021

(c) The Author(s) 2021

\begin{abstract}
Drought is the absence or below-required supply of precipitation, runoff and or moisture for an extended time period. Modelling drought is relevant in assessing drought incidence and pattern. This study aimed to model the spatial variation and incidence of the 2018 drought in Brandenburg using GIS and remote sensing. To achieve this, we employed a Multi-Criteria Approach (MCA) by using three parameters including Precipitation, Land Surface Temperature and Normalized Difference Vegetation Index (NDVI). We acquired the precipitation data from Deutsche Wetterdienst, Land Surface Temperature and NDVI from Landsat 8 imageries on the USGS Earth Explorer. The datasets were analyzed using ArcGIS 10.7. The information from these three datasets was used as parameters in assessing drought prevalence using the MCA. The MCA was used in developing the drought model, 'PLAN', which was used to classify the study area into three levels/zones of drought prevalence: moderate, high and extreme drought. We went further to quantify the agricultural areas affected by drought in the study area by integrating the land use map. Results revealed that $92 \%$ of the study area was severely and highly affected by drought especially in districts of Oberhavel, Uckermark, Potsdam-Staedte, and Teltow-Flaeming. Finding also revealed that $77.54 \%$ of the total agricultural land falls within the high drought zones. We advocated for the application of drought models (such as 'PLAN'), that incorporates flexibility (tailoring to study needs) and multi-criteria (robustness) in drought assessment. We also suggested that adaptive drought management should be championed using drought prevalence mapping.
\end{abstract}

Keywords Drought $\cdot$ Land surface temperature $\cdot$ Brandenburg $\cdot$ NDVI $\cdot$ Agriculture

\section{Introduction}

Climate change and the associated increase in temperature are causing a variety of extreme weather events such as droughts (IPCC 2019; Buras et al. 2020). The Convention to Combat Desertification of the United Nations considered droughts as one of the most far-reaching natural disasters, causing short- and long-term economic and social losses for millions of people worldwide. Many countries around the world are facing the consequences of drought.

Christopher Ihinegbu

ihinegbu@ehs.unu.edu

1 United Nations University-Institute for Environment and Human Security, UN Campus, Platz der Vereinten Nationen 1, 53113 Bonn, Germany

2 Department of Geography, University of Bonn, Bonn, Germany

3 Department of Geography, University of Nigeria, Nsukka, Nigeria
The agricultural and food production sectors, in particular, are struggling with the consequences, such as dry shocks and losses in food production. Droughts also have a major impact on human health, economic growth, and poverty (FAO 2019).

To detect and monitor droughts, indices are used and thus provide a useful means of scientifically assessing the extent and impact of droughts and making policy recommendations (Mishra and Singh 2011; Deutscher Wetterdienst 2021). According to the measurements of the German Institute for Drought Monitoring (Helmholtz Centre for Environmental Research), Germany was affected by a historic drought event in 2018. This drought was drier than in all previously available years since 1951 (Helmholtz Institut 2020). Brandenburg, a German federal state, is dominated by agricultural and large forest areas. It has experienced the most severe droughts in April until November 2018, which have caused economic damage and led to the payment of 72 million euros from public funds to farmers (KIT 2018; Reinermann et al. 2019; Buras et al. 2020). 
In reference to modelling drought, several approaches exist. Approaches can be probabilistic (Cancelliere et al. 2007; Mishra and Singh 2011), artificial neural-based (Mishra and Desai 2006; Morid et al. 2007), hybrid (Kim and Valdes 2003; Mishra et al. 2007), author-defined (which is usually based on one or more index, for example, Berhail et al. 2021). Irrespective of the models applied, the indices used are usually one or a combination of climatic and hydro-meteorological variables (Mishra and Singh 2011). Numerous works have been done on drought modelling. For instance, Yisehak and Zenebe (2021) modelled drought of the Ethiopian Rift Valley Basin using the multivariate standardized drought index (MSDI). The model was based on the drought information derived from the standardized precipitation index (SPI) and standardized runoff index (SRI). Berhail et al. (2021), in their geostatistical assessment of drought in Algeria, employed the standardized precipitation index (SPI) to assess the spatial and temporal dynamics of meteorological drought over 42 years. In a review on drought modelling, Mishra and Singh (2011) concluded that drought modelling involving multi parameters were more desirable and that multi-criteria decision analysis should be applied in making an informed decision in modelling drought.

Several allied research has been done in the study area. For example, Schindler et al. (2007) evaluated the current situation and continuing development of drought risk to agricultural land in Northeast (NE) and Central Germany based on soil-hydrological data that revealed the strongest water deficit in Brandenburg and Saxony-Anhalt. Holsten et al. (2009), based on the trend in soil water moisture in Special Areas of Conservation (SACs), investigated past trends and future effects of climate change on soil moisture dynamics in Brandenburg. Reyer et al. (2012) in their study of adaptation measures to climate change in Brandenburg identified summer drought and its cascading effects (decreasing groundwater tables, water stress, fire risk, productivity losses) to be the most vulnerable climate condition in Brandenburg. Bloch, Wechsung and Hess (2015) applied weather data series in evaluating the impact of climate change on legume-grass swards production in Brandenburg. Their result showed a $20 \%$ reduction in annual yield which was mainly attributed to drought impact in the region. From the foregoing, we can deduce that these studies have made valuable contributions to our understanding of climate change impacts, drought risks, and climate change adaptation in Brandenburg. However, there remains a need to systematically study the incidence and spatial variation of drought in Brandenburg, especially as the Helmholtz Institut (2020) has identified the 2018 drought to be drier than in all previously available years since 1951 in Brandenburg. This would contribute to German drought monitoring and adaptive management.

It is, therefore, pertinent to understand the severity and effects of this drought in the study area. In the context of the described relevance, this paper aims to examine the incidence and spatial variation of the 2018 drought in Brandenburg using GIS and Remote Sensing. This study has four objectives: (a) examine the degree and incidence of drought in Brandenburg Federal State, (b) examine the spatial variation in the incidence of drought among the various districts, (c) examine the intensity of drought on agricultural lands and food security and (d) suggest possible solutions to improve drought monitoring, remediation, and management. This paper is structured as follows. The next section reviews the methods employed. This is followed by a presentation of the results of this paper. After the result presentation is the discussion of the resultant implications. The last section concludes and provides recommendations.

\section{Material and methods}

\section{Study area}

Brandenburg Federal State, the study area, is in NorthEast Germany (Fig. 1) and it occupies an area of 29,478 $\mathrm{km}^{2}$ and is majorly an agricultural state, with about $45 \%$ of its area comprising agricultural land (Amt für Statistik Berlin-Brandenburg 2016). Of the total agricultural land, $77 \%$ is dedicated to cropland and $23 \%$ permanent grassland (Troegel and Schulz 2018). Brandenburg entirely borders Germany's capital city of Berlin (Fig. 1), which is highly urbanized. Food demand in the neighbouring state has been on the increase, as has the use of cropland for the production of renewable energy (Gutzler et al. 2015), which has triggered the considerable rise in maize production for cheaper biogas fermentation in Brandenburg (Wolff et al. 2021).

Brandenburg is one of the warmest regions in Germany with a mean daily high temperature of 14 degrees centigrade (World Data 2021). The climate type in Brandenburg is temperate with warm summers and relatively warm winters. According to the German Weather Service-Deutscher Wetterdienst (2020), the mean annual temperature in Brandenburg was 10.9 degrees Celsius, while in winter the air temperature was on average $4.7^{\circ} \mathrm{C}$, and in summer $19.2^{\circ} \mathrm{C}$. It has a precipitation of less than $600 \mathrm{~mm}$ and thus, one of the aridest and vulnerable regions to climate change in Germany (Kipping 2020).

\section{Data sources and processing}

This project applied a Multi-Criteria Approach (MCA) using precipitation, Land Surface Temperature (LST), and Normalized Difference Vegetation Index (NDVI) to determine the incidence and spatial variation of drought in Brandenburg. Finally, Land Use and Land Cover Classification (LULC) was used to determine the effect of 


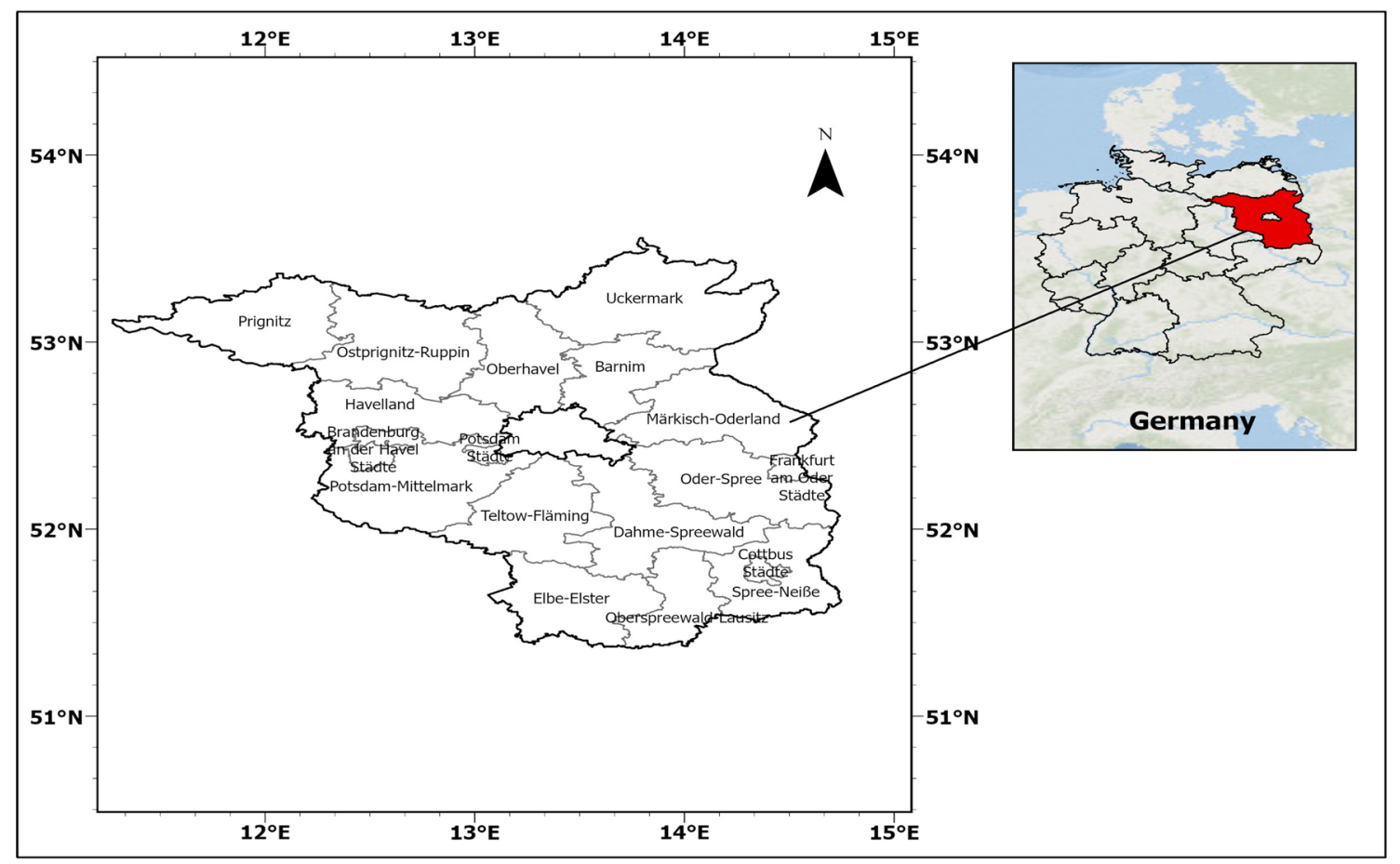

Fig. 1 The study area

drought on agricultural lands. The MCA has been applied and appraised by various scholars (Agboola and Ayanlade 2016; Malik and Abdalla 2016; Erfurt et al. 2019; Brito et al. 2020) for its robustness in decision making. A diagrammatic representation of the approach employed is visualized in Fig. 2.

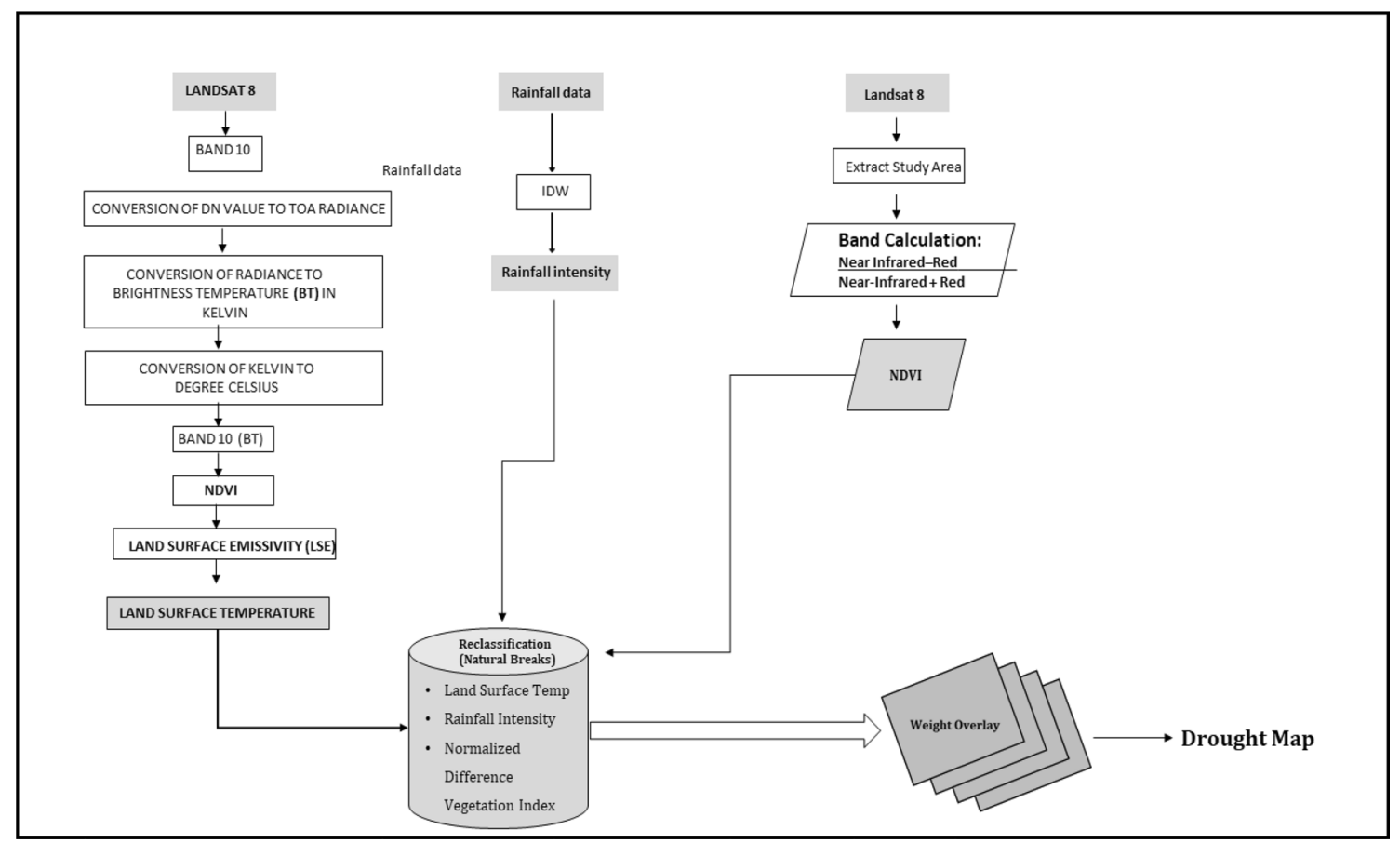

Fig. 2 Diagrammatical presentation of the methods employed 
The first step in this project was sourcing the various drought indices. The precipitation data of all weather stations (55) across Brandenburg was sourced from the website "www.wetterkontor.de". The data was imported as points into GIS and was used to prepare the precipitation map using the IDW interpolation method (Fig. 3). The Normalized Difference Vegetation Index (NDVI) was derived from cloudfree Landsat 8 Operational Land Imager (OLI) sourced from USGS Earth Explorer. The land surface temperature was prepared from Band 10 of Landsat 8 images and processed in ArcGIS 10.7 software using the method applied by Sobrino et al. (2004). The LULC was also derived from processing Landsat 8 Operational Land Imager (OLI) in ArcGIS 10.7, using the Interactive Supervised Classification method.

The second step in this project involved the reclassification of our drought indices into three equal classes each (Moderate, High, and Extreme drought). This was done to better visualize the spatial variation in the occurrence of drought in the study area. The final stage of this project was the weighting process in ArcGIS 10.7 software, where different weights of influence were assigned to the different indices to generate the drought prevalence map. In combination with the LULC, we were able to determine the agricultural areas of Brandenburg that may be exposed and impacted by the drought events using the intersect tool in ArcGIS.

The integration of precipitation and remote sensing data was used to estimate the Precipitation (P), Land Surface Temperature (LA) and Normalized Difference Vegetation
Index $(\mathrm{N})$. These three parameters were used to develop our 'PLAN' model. This model was then used to assess the prevalence of drought in the study area (see Fig. 2).

To validate this model, we compared our findings with existing literature on drought and with the German Drought System (Wetterkontor) in the study area.

\section{Development of 'PLAN' model}

This study employed the Multi-criteria approach (MCA) in the context of the analytic hierarchy process (AHP) as proposed by Saaty (1980) to determine and assign weights/ influence to the three identified parameters [Precipitation (P), Land Surface Temperature (LA) and Normalized Difference Vegetation Index $(\mathrm{N})$ ]. This method helps to organize and analyze complex decisions based on the importance of each parameter in the study context (Fig. 2). To develop this model (used to assess drought prevalence in Brandenburg), we employed the following procedure:

(a) Identification and selection of factors indicating drought intensity in the study area. These factors include Precipitation (P), Land Surface Temperature (LA) and Normalized Difference Vegetation Index (N),

(b) Processing of individual parameters

(c) Determination and assigning of weight values to factors/parameters

(d) Reclassification and rating of study parameters

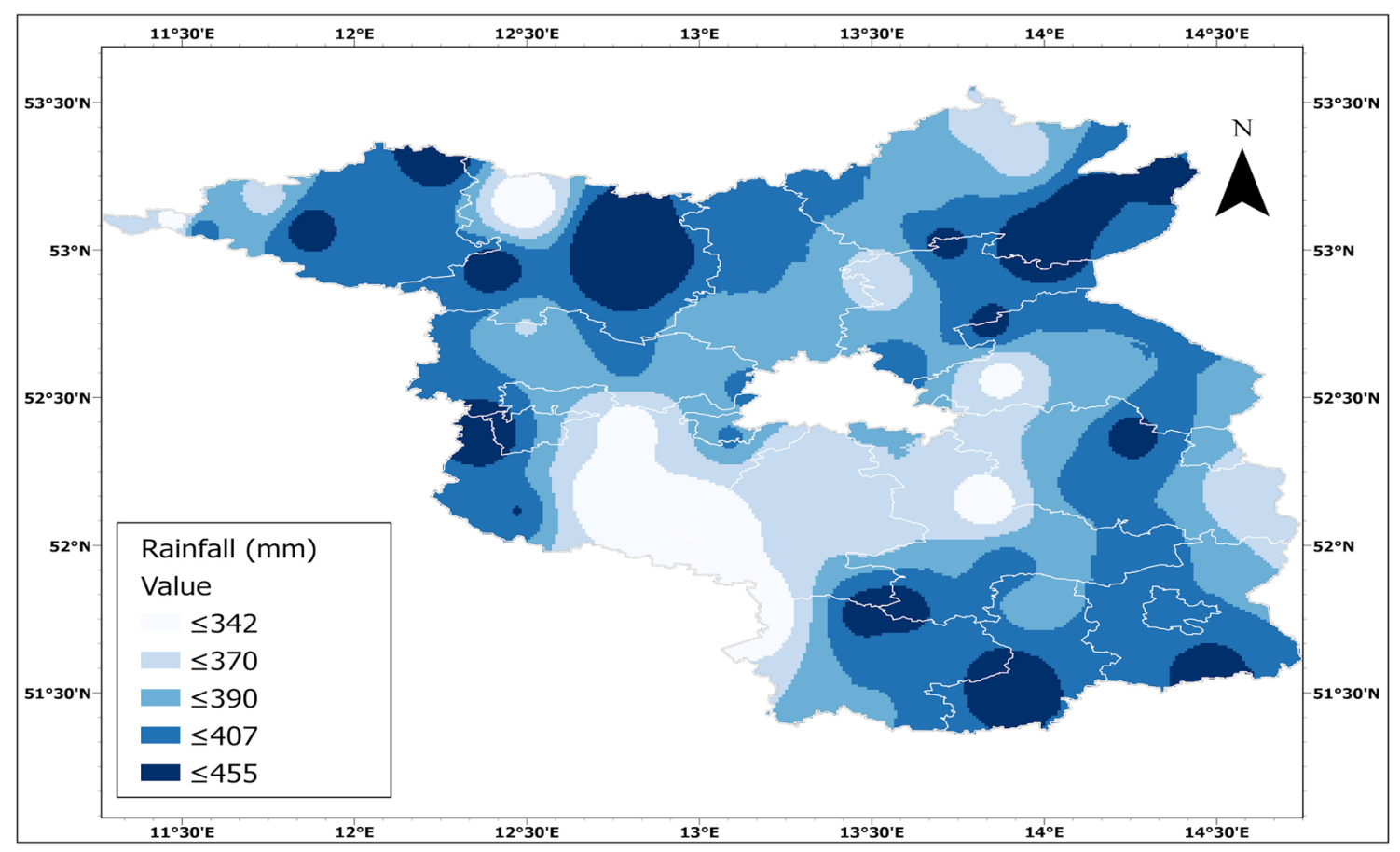

Fig. 3 Precipitation distribution in Brandenburg for 2018 
(e) Estimation of drought prevalence (pattern and intensity)_'PLAN' model; and

(f) Validation of the 'PLAN' model in (e) above

\section{Study parameters}

A brief overview of the parameters and the processing employed is presented below.

\section{Precipitation (P)}

To show the spatial variation and amount of precipitation in 2018, we retrieved the average annual rainfall data for all 55 weather stations in Brandendurg from the website of the "Wetterkonto". The rainfall data and the coordinates of the respective weather stations were collected in Excel file format. This data was imported into the ArcGIS software for further processing and interpolation of the rainfall dataset. With the precipitation data and the corresponding coordinates, we were able to generate a map that shows the spatial variation of precipitation amounts throughout Brandenburg. The rainfall data is an important indicator for the aridity in a region of study (Fig. 3).

\section{Land surface temperature (LA)}

The Land Surface Temperature (LST), is the radiative skin temperature of the land surface, as measured in the direction of the (remote) sensor. The LST is not the temperature of the air and, therefore, highly dependent on the surface which is being measured. Its estimation highly depends on the albedo, the vegetation cover, and the soil moisture of the measured object. All these factors highly influence the surface temperature of an object. For example, a rooftop is going to have a much different surface temperature than a forest or an agricultural area. The LST is often measured with remote sensing satellites because it is possible to measure big areas, quick and cheap.

We generated the LST from the thermal band of the Landsat 8 images, which is band 10 . We generated the LST by using the USGS method applied by Sobrino et al. (2004) for LST creation. Therefore, we followed the following procedure and applied them in the raster calculator in ArcGIS 10.7:

(a) Conversion to TOA (Top of Atmospheric) tadiance

$$
L \lambda=M l Q c a l+A l
$$

where; $L \lambda=$ TOA spectral radiance. $M l=$ Band-specific multiplicative rescaling factor from the metadata. Qcal $=$ Quantized and calibrated standard product pixel values (band 10 image). $A l=$ Band-specific additive rescaling factor from the metadata.

(b) Conversion to top of atmospheric brightness temperature

$T \frac{K_{2}}{\operatorname{Ln}\left(\frac{K_{1}}{L \lambda}+1\right)}-273.15^{\circ} \mathrm{C}$

$T=$ Top of atmosphere brightness temperature (K).

$K_{1}=$ Band-specific thermal conversion constant from the metadata (K1_CONSTANT_BAND).

$K_{2}=$ Band-specific thermal conversion constant from the metadata (K2_CONSTANT_BAND).

$L \lambda=$ TOA spectral radiance.

(c) Estimation of LSE (Land Surface Emissivity)

$e=0.004 P V+0.986$

where

$e=$ emissivity

$$
\begin{aligned}
P V & =\text { proportion of vegetation } \\
& =\left(\frac{\text { NDVI }- \text { NDVImin }}{\text { NDVImax }- \text { NDVImin }}\right)^{2}
\end{aligned}
$$

(d) Estimation of LST (Land Surface Temperature)

$$
L S T=\frac{T}{1}+W\left(\frac{T}{P}\right) \operatorname{Ln}(e)
$$

where

$W=$ wavelength of emitted radiance (11.5 v́m)

$P=h \frac{c}{s}$

$h=$ Plancks constant $\left(6.626 \times 10^{-34} \mathrm{JS}\right)$

$s=$ Boltzmann constant $\left(1.38 \times 10^{-23} \mathrm{~J} / \mathrm{K}\right)$

$c=$ velocity of light $\left(2.998 \times 10^{8} \mathrm{~m} / \mathrm{s}\right)$

The product of this method is a map, showing the spatial variation of the LST in Brandenburg. The LST is a good method to highlight seasonal climatic fluctuations. Combining the results of the LST with other measures, such as the NDVI, gives a great opportunity to understand and analyze droughts very well with remote sensing data (Karnieli et al. 2003). 


\section{Normalized difference vegetation index (N)}

The NDVI (Normalized Difference Vegetation Index) is a simple graphical indicator calculated using remote sensing data. It is one of the most commonly used vegetation indices in environmental studies (Benedetti and Rossini 1993; Moulin et al. 1998; Wolff et al. 2021). The vegetation index uses the different reflections of the cell structures of plants, such as the mesophyll cells in leaves. Healthy vegetation reflects a lot of radiation in the near-infrared range, which includes a wavelength of 700-1300 $\mathrm{nm}$. In contrast, little radiation is reflected in the red region of the visible spectrum, which is a wavelength of 600-700 $\mathrm{nm}$. The greener a plant is, the greater the increase in reflectance. Based on these increases, various surface materials can be distinguished from one another. The NDVI is the difference between reflected Red (RED) and Near Infrared radiation (NIR) divided by their sum (Rouse et al. 1974) and can therefore be calculated from the formula:

$$
\mathrm{NDVI}=\frac{\mathrm{NIR}-\mathrm{RED}}{\mathrm{NIR}+\mathrm{RED}}
$$

The NDVI values range from - to +1 . The negative limit value is derived from water, while the positive limit value indicates high vegetation. The NDVI cannot take values above 1, which can be biased in heavily vegetated areas because biomass can increase despite the NDVI limitation (Sobrino et al. 2004).

\section{Land use and land cover classification}

Land cover maps represent spatial information on different types (classes) of physical coverage of the earth's surface, e.g. forests, grasslands, croplands, lakes, wetlands. Land cover is the observed (bio)physical cover on the earth's surface. A suitable land cover map should be dynamic to capture the changing features on the earth surface (Njoku et al. 2018). The LULC map was produced using cloud-free images of Landsat 8 images from USGS Earth Explorer in ArcGIS 10.7. We created a composite image with all the bands of Landsat 8 and trained our samples. While training our samples, we constantly changed our visualization from true to false-colour composite for best classification (see Figs. $4 a-c)$. We also ensured we selected a minimum of 50 training samples for each land-use class (for better output). For this study, we used five classes namely: Heavy vegetation (forests), Light vegetation (agriculture), waterbody, urban area, and bare soils using the Interactive Supervised Classification method in ArcGIS 10.7 (Fig. 5).

\section{Reclassification of parameters for further analysis}

In this study, each of the parameters was reclassed into three classes (moderate, high, and extreme drought) using the natural break methods as shown in Table 1 . We choose this reclassification method for our study as the 2018 drought in Brandenburg and Germany at large was drier than any previously available years since 1952 (Helmholtz Institut 2020; Deutscher Wetterdienst 2021).

This rating is user-defined, supported by literature, and also depending on their significance of influence on drought prevalence (Muthumanickam et al. 2011; Murthy et al. 2015; Olaseeni et al. 2021). The ranks were further grouped into a rating index of extreme, high, and moderate drought (Table 1).

\section{Weighting process}

Weight values represent the priorities assigned to the study indices which are absolute numbers between zero and $100 \%$. This means that the sum of weights assigned to all parameters should be $100 \%$. Table 1 gives an overview of the drought parameters and how they were rated according to their influence on drought events in the study area.

The weight apportioned for each criterion/index is often based on expert knowledge of the importance of

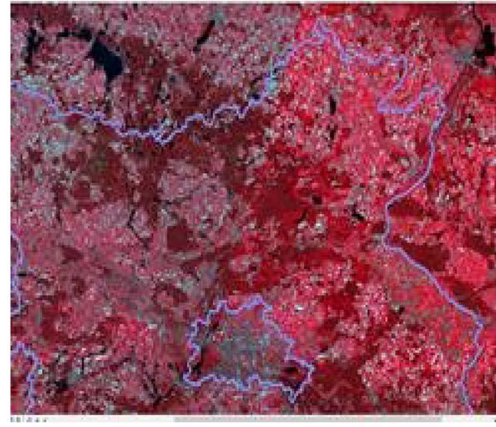

a

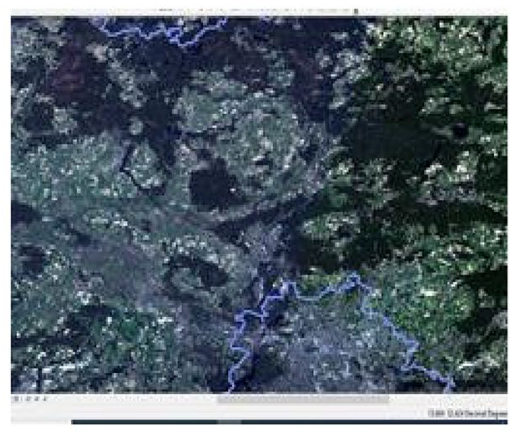

b

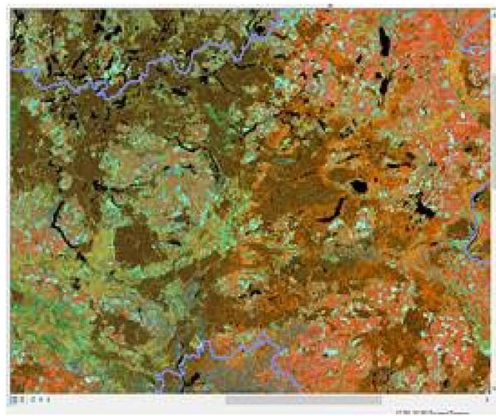

c

Fig. 4 a False colour composite. b True/natural colour composite. c Water composite 


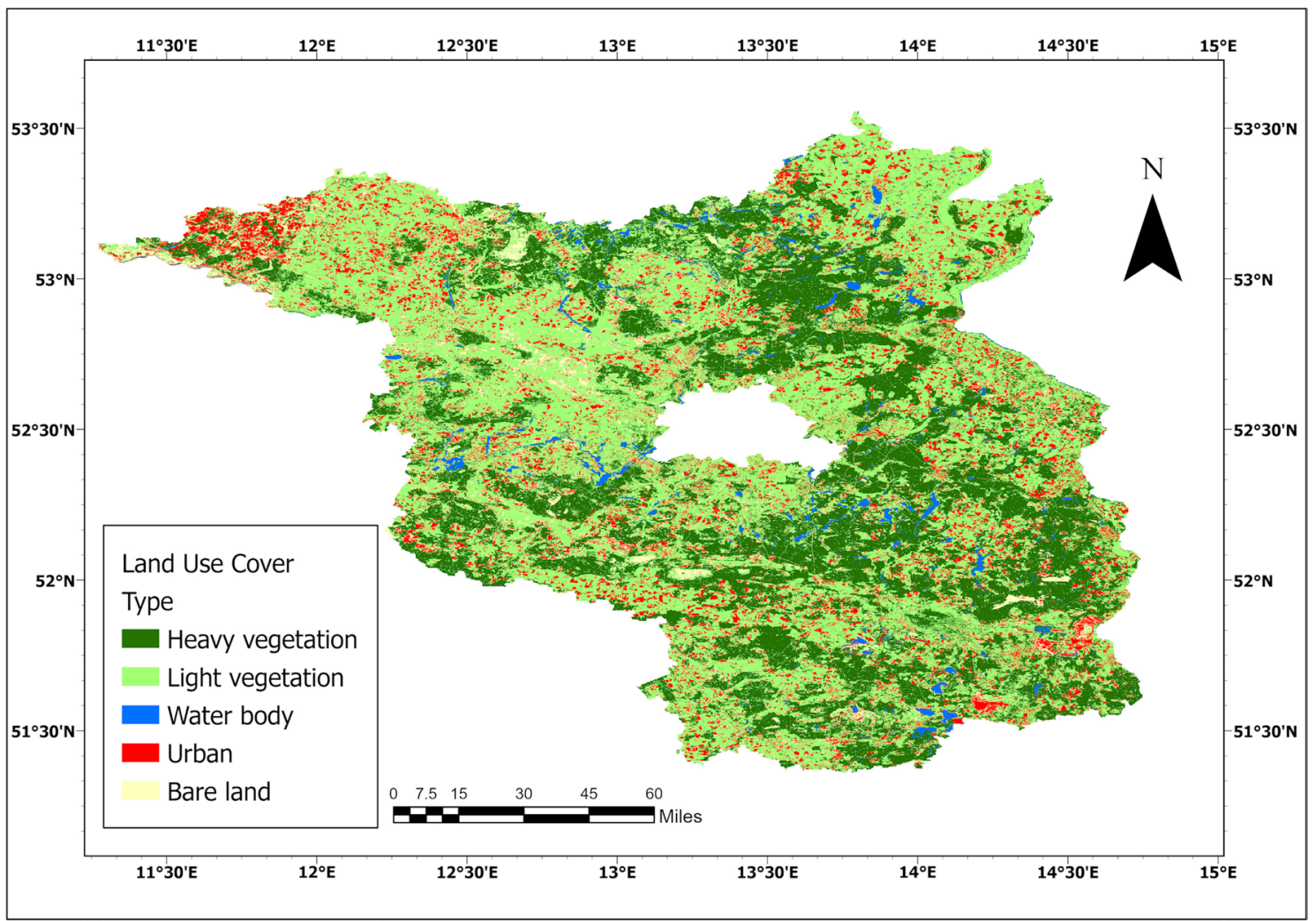

Fig. 5 LULC of Brandenburg

Table 1 Multi-criteria analysis parameters

\begin{tabular}{lllll}
\hline Parameter/index & Classes & Reclass & Rating index & Weighting (\%) \\
\hline Land surface temp & $-0.60-14.7$ & 3 & Moderate drought & $40 \%$ \\
& $14.8-30.2$ & 2 & High drought & \\
& $30.3-45.6$ & 1 & Extreme drought & \\
Rainfall & $287.8-343.7$ & 1 & Extreme drought & $40 \%$ \\
& $343.8-399.6$ & 2 & High drought & \\
& $399.7-455.5$ & 3 & Moderate drought & \\
NDVI & $-1.021-0.289$ & 1 & Extreme drought & $20 \%$ \\
& $0.290-0.442$ & 2 & High drought & \\
Total weighting & $0.443-0.674$ & 3 & Moderate drought & \\
\hline
\end{tabular}

Source: authors analysis each parameter and sometimes based on analytical procedures and literature. Bhuiyan et al (2006) work on drought assigned equal importance to NDVI, LST, and rainfall. The work of Njoku (2018) on flood susceptibility, assigned the highest weighting to proximity to the river followed by elevation and slope. For this study, LST and Rainfall were assigned a weight of $40 \%$ each while the NDVI was assigned a weight of $20 \%$. The NDVI was assigned the lowest weight because it might not truly reveal the arid condition of the study area. This is because Brandenburg, an agricultural area, is mainly mechanized and irrigated.

To generate the drought prevalence map of the study area, each factor was weighted according to their estimated significance specified in Table 1 . The weighted overlay analysis tool on ArcGIS 10.7 was used to integrate the rates and weights and to generate a drought prevalence map of Brandenburg. The drought prevalence map was 
classified into 3 zones: extreme, High, and moderate drought, respectively.

\section{Results}

\section{Precipitation (P)}

From the precipitation map (Fig. 3), it is evident that the lowest annual precipitation was recorded by Potsdam, Mittelmark, and Teltow-Flaming districts while OberspreewaldLausitz, Cottbus-Staedte received the highest precipitation for the year 2018. It is important for us to understand the spatial variations of precipitation distribution among the districts of Brandenburg with a rainfall amount between 288 and $455 \mathrm{~mm}$ in 2018. In comparison to the annual precipitation of 2016 (Deutscher Wetterdienst 2020), the values range from 373 to $633 \mathrm{~mm}$ which points to a precipitation decrease in 2018.

\section{Land surface temperature (LA)}

The LST map in Fig. 6 shows that the lowest temperature was recorded in Barnim, Prignitz districts while the highest temperatures were recorded in the Southern parts of Brandenburg including Elbe-Elster, Cottbus Staedte. What this means, according to Ibrahim et al. (2016), is that the heating effect would be more obvious in these areas and therefore, requires several adaptive measures to mitigate the adverse impacts of temperature extremes.

\section{NDVI (N)}

As can be seen from Fig. 7, the NDVI value for Brandenburg ranges from -1.02 to 0.67 . A mere glance at the map shows that the majority of the study area falls within the NDVI threshold of 0.5 and 0.67 as the study area is mainly agrarian. The predominance of agricultural land use in Figs. 5 and 8 is an empirical confirmation of the result of the NDVI map.

\section{Land use and land cover classification}

For this paper, we classified the land use of the study area into five classes namely: heavy vegetation (forests), light vegetation (agriculture), waterbody, urban area and bare soils using various colour composite (Fig. $4 \mathrm{a}-\mathrm{c}$ ) and the Interactive Supervised Classification method. Table 1 shows a summary of the classification result according to the area and percentage covered by each class.

The LULC map in Fig. 5 shows that Brandenburg is predominantly an agricultural area with $73 \%$ of its total area covering heavy and light vegetation. This is an empirical confirmation of our NDVI analysis in Fig. 7.

\section{Drought prevalence in Brandenburg ('PLAN' model)}

For this paper (creating a drought prevalence map of Brandenburg, using the 'PLAN' model), we reclassified the study parameters [Precipitation (P), Land Surface Temperature (LA) and Normalized Difference Vegetation Index (N)] using the reclass tool in ArcGIS 10.7. We
Fig. 6 Land surface temperature of Brandenburg in 2018

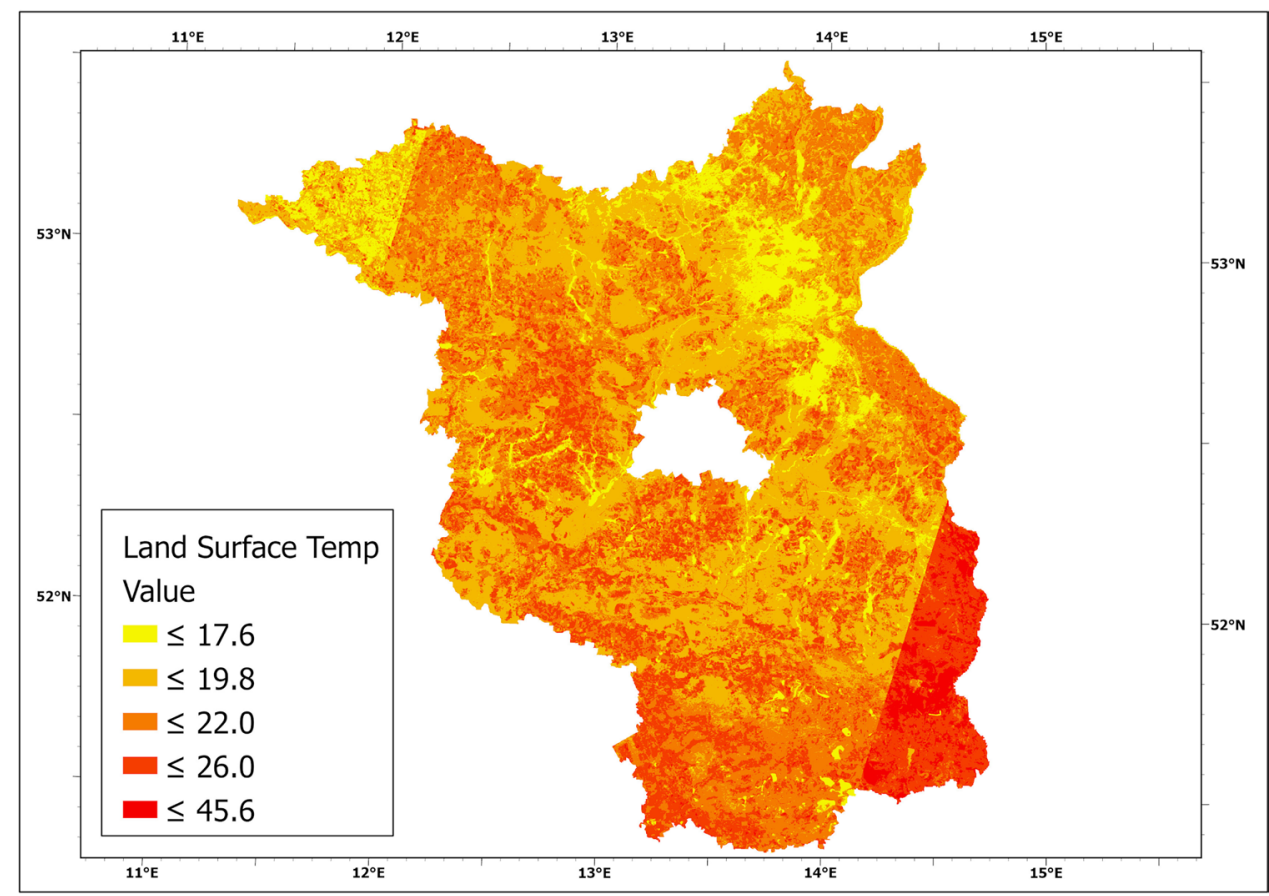




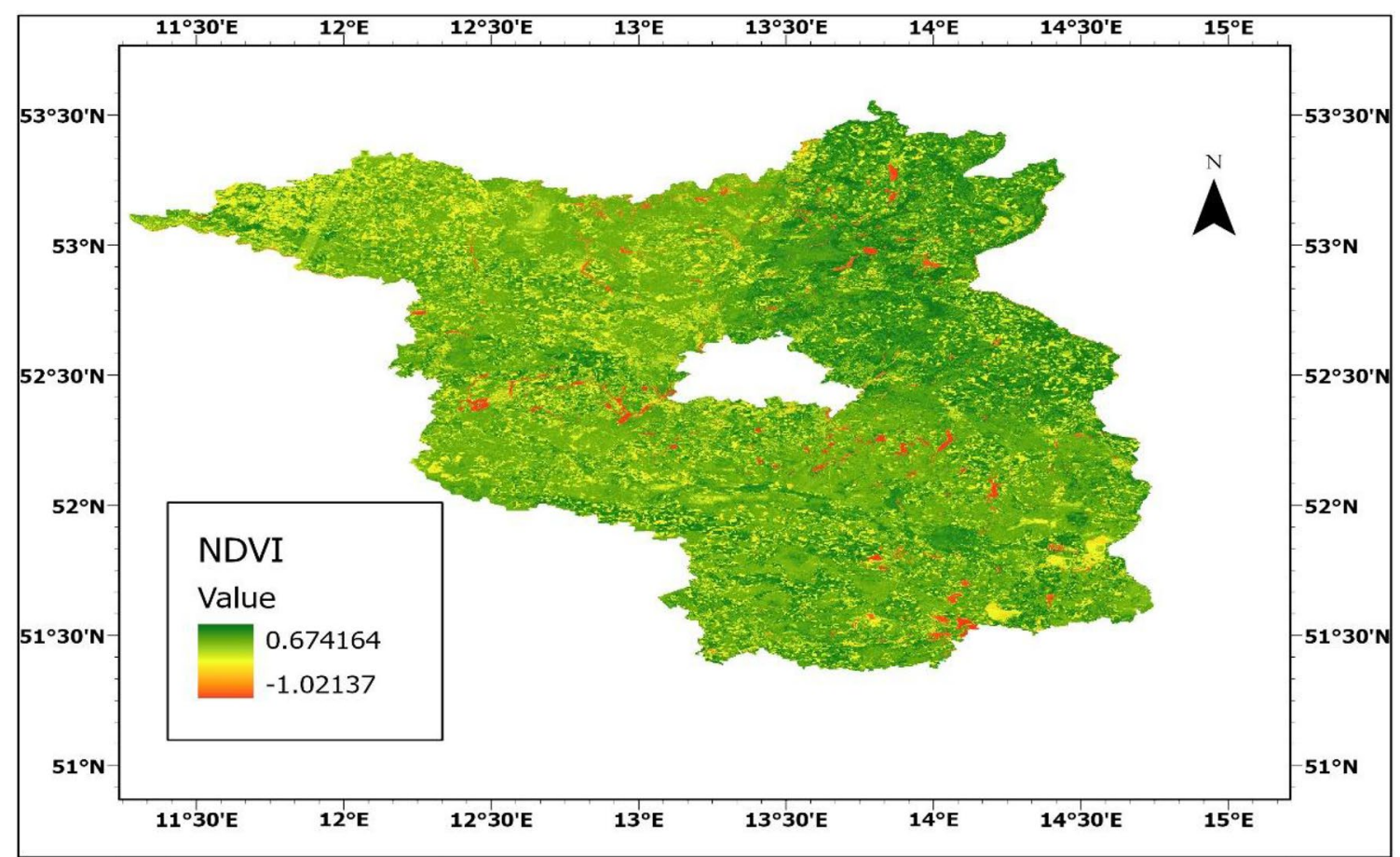

Fig. 7 NDVI map of Brandenburg for 2018

Fig. 8 Reclassified LULC

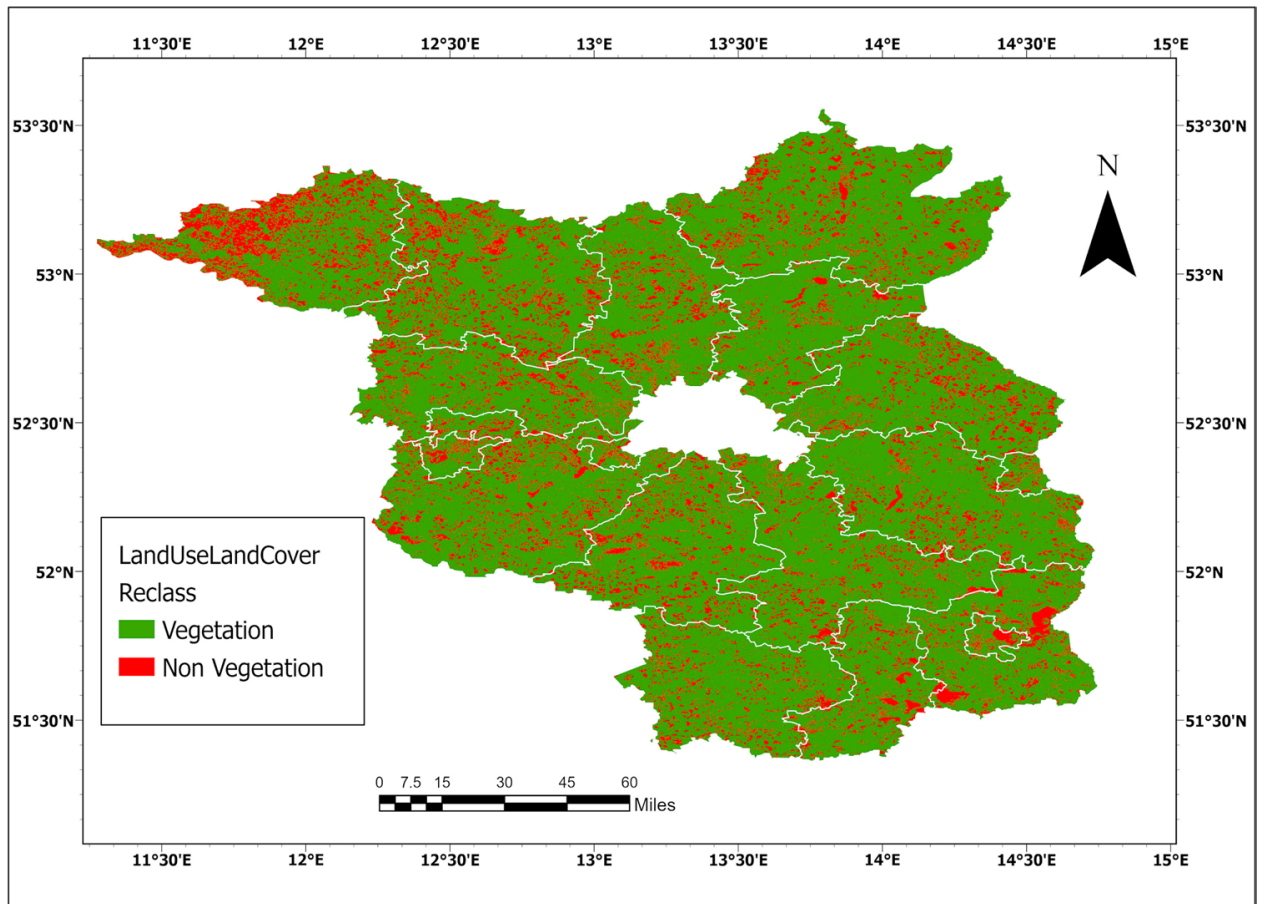

reclassified them into three equal classes each and ranked them accordingly: Extreme drought, High rought, and Moderate drought (Table 2). The results of the reclassification are shown in Figs. 9, 10, and 11.
Following the procedures of the 'PLAN' model, the drought prevalence map was generated in ArcGIS 10.7. Figure 12 visualizes the spatial variation in the prevalence of 2018 drought amongst the Brandenburg districts while 
Table 2 Summary of LULC analysis

\begin{tabular}{lll}
\hline Land Class & Area $(\mathrm{SqKm})$ & Percentage $(\%)$ \\
\hline Heavy vegetation & $11,659.09$ & 39.55 \\
Light vegetation & $9,949.28$ & 33.75 \\
Water body & 642.72 & 2.18 \\
Bare land & $2,112.05$ & 7.16 \\
Urban areas & $5,114.85$ & 17.35 \\
Total & 29,478 & 100 \\
\hline
\end{tabular}

Source: authors analysis

Table 3 shows the drought prevalence in terms of the land area covered. A glance at Fig. 12 shows that drought was generally experienced by all districts in the study area.

Following from the result in Fig. 12, the classes of drought identified at the district level are presented in Table 4.

\section{Drought and agriculture}

For a more focused policy recommendation, the extent of agricultural lands (including forests) impacted by the 2018 drought in the region (as the region is predominantly agrarian) was examined. For this, the LULC map was reclassed into two classes: agricultural and non-agricultural land use. The heavy and light vegetation were grouped into agricultural land use while the water body, urban and bare soils were grouped into the non-agricultural land use. The reclassified LULC map is shown in Fig. 8. Figure 8 shows that $73 \%$ of the study area is either an agricultural or forested area while Fig. 13 shows the agricultural lands that fall within the high drought zone. This is relevant because hazards events (drought, in this context) translates to risk when an exposed element (agricultural lands, in this context) is affected (IPCC 2019).

Table 5 shows the grouping of the study area into agricultural and non-agricultural land use which re-emphasizes the claims of Troegel and Schulz (2018), while Table 6 summarizes the relationship between agricultural lands and drought in 2018 and this shows that $77 \%$ of the total agricultural land were impacted by high drought. This is thus a severe threat to food security and the sustainability of agriculture, the major economic activity in Brandenburg.

\section{Discussion}

The results of this paper all agree with the severity of the 2018 drought in the study area. While the precipitation (P) analysis suggests that drought was most severe in Oberspreewald-Lausitz and Cottbus-Staedte districts, the Land Surface Temperature (LA) suggests that drought was most severe in Elbe-Elster and Cottbus Staedte districts. However, the Normalized Difference Vegetation Index (N), suggests that the occurrence of the drought was evenly distributed in the study area. To make a more informed decision in drought assessment, a multi-criteria approach that incorporates relevant parameters must be adopted. Hence, the validity of the 'PLAN' model. The drought prevalence map went further to show that a high proportion of the study area was highly affected by drought. Figure 12 and Table 3 further revealed

Fig. 9 Reclassified precipitation

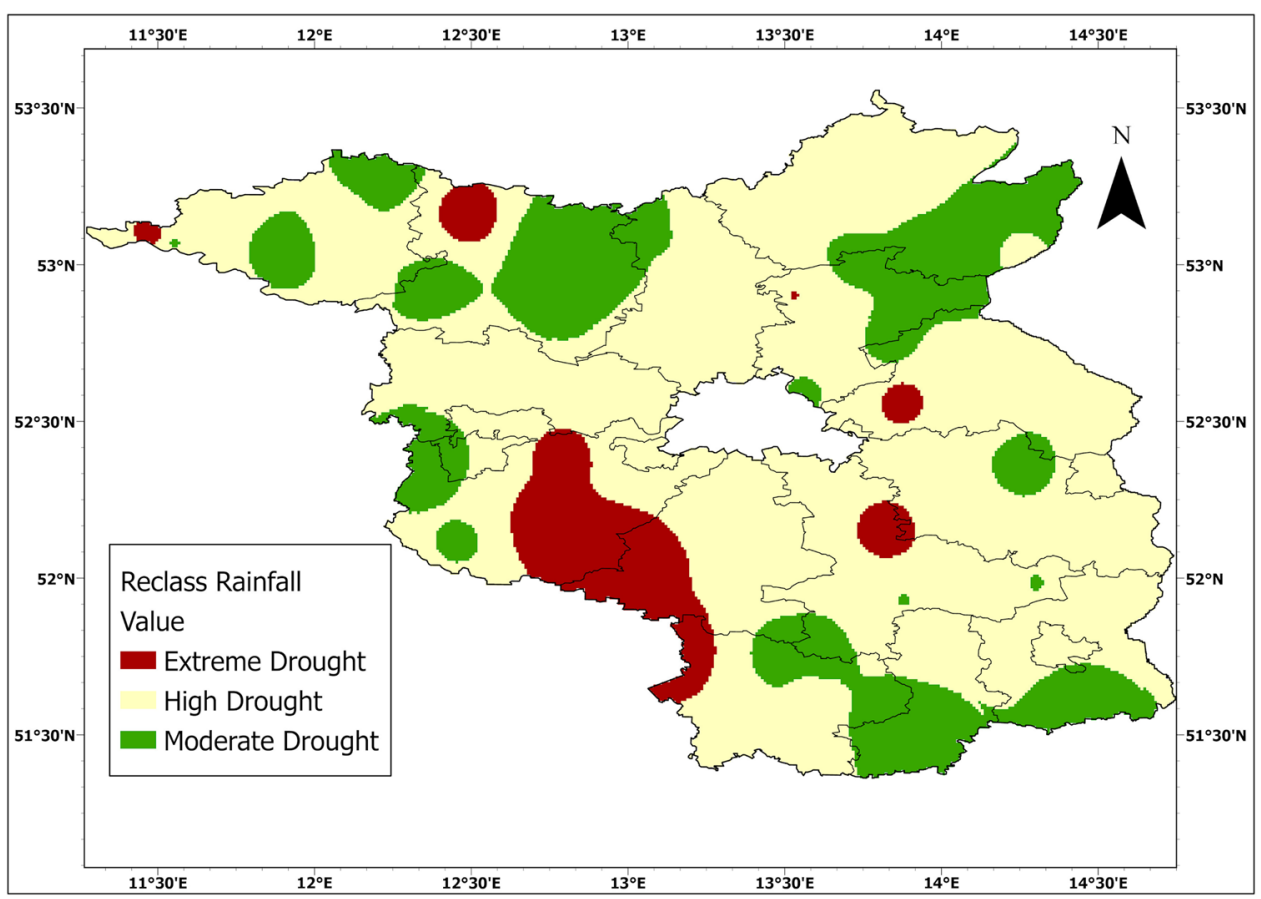




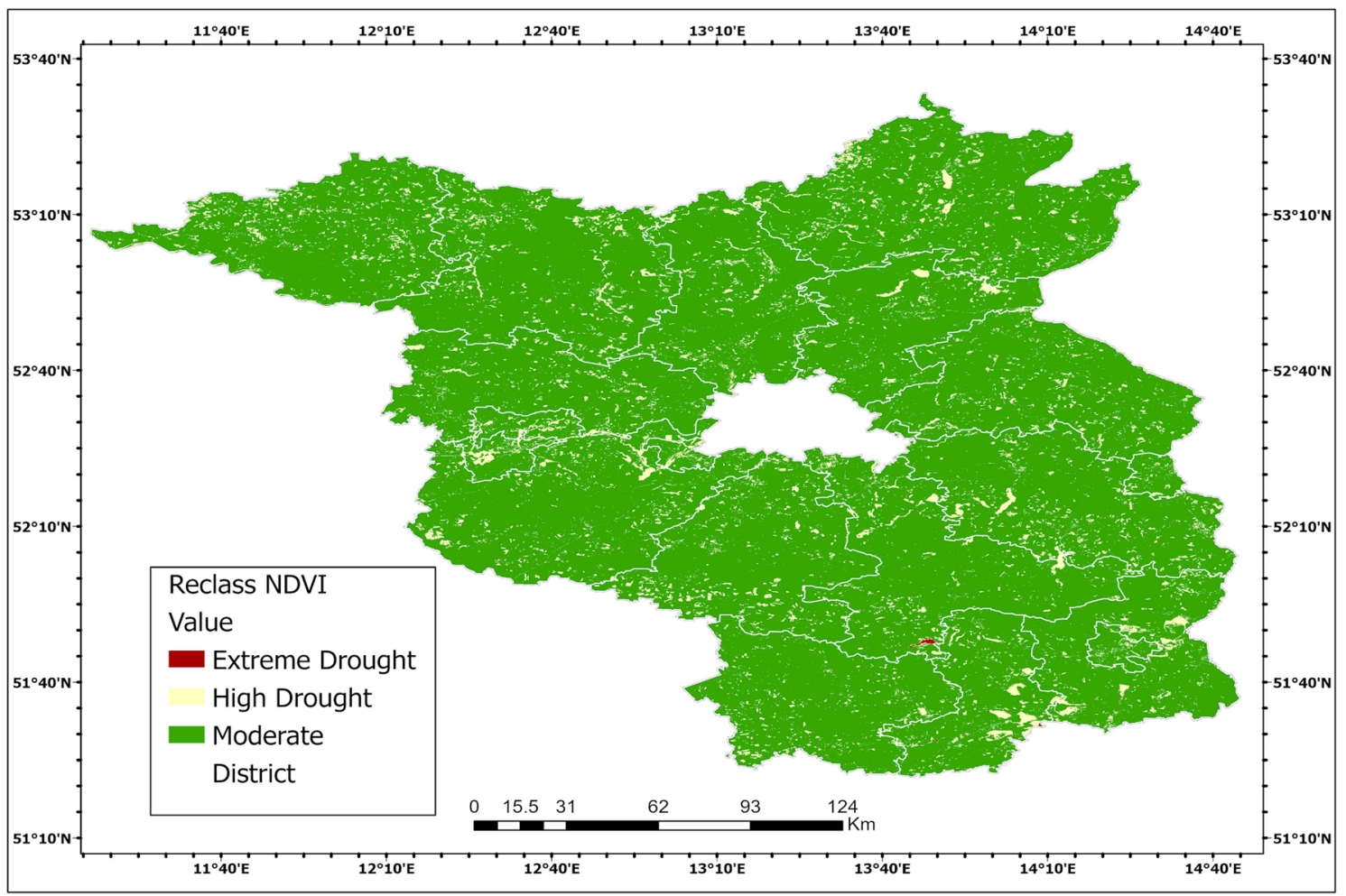

Fig. 10 Reclassified NDVI

Fig. 11 Reclassified LST

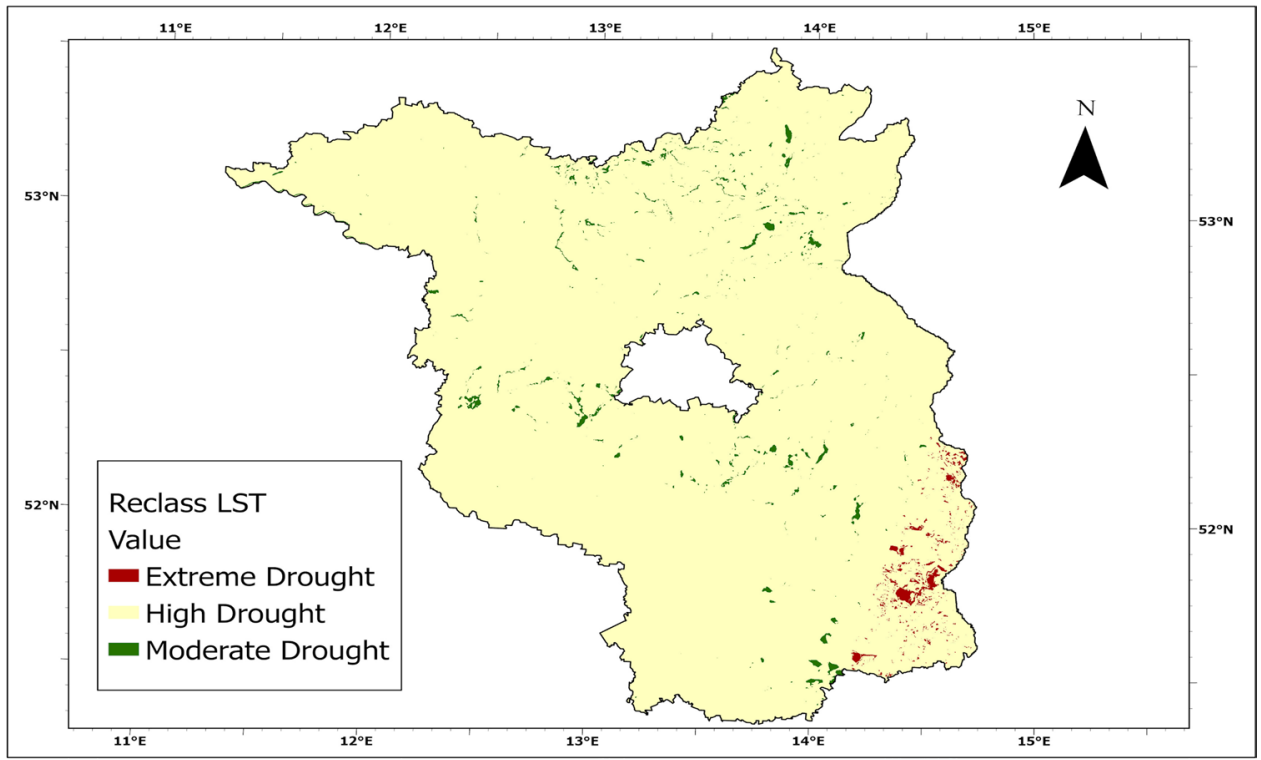

that $91 \%$ of the region (of which agriculture accounts for $73 \%$ ) were highly impacted by drought. Figures 4 and 13 reveal that $77.54 \%$ of the total agricultural areas were highly impacted by drought. This is threatening to food security in the region and Germany at large as Brandenburg is predominantly agrarian. Our results agree with that of Reinermann et al. 2019; Buras et al. 2020; Deutscher Wetterdienst 2020;
Deutscher Wetterdienst 2021. These findings also agree with Erfurt et al. (2019) who went further to highlight the adverse effects of the 2018 drought on agriculture in the region. They attributed crop failure, earliness of harvests, early slaughtering, rapid sale of produce, loss of earnings in agriculture, and damage to silviculture to the 2018 drought in the region. Brito et al. (2020) also affirmed that the agricultural sector 


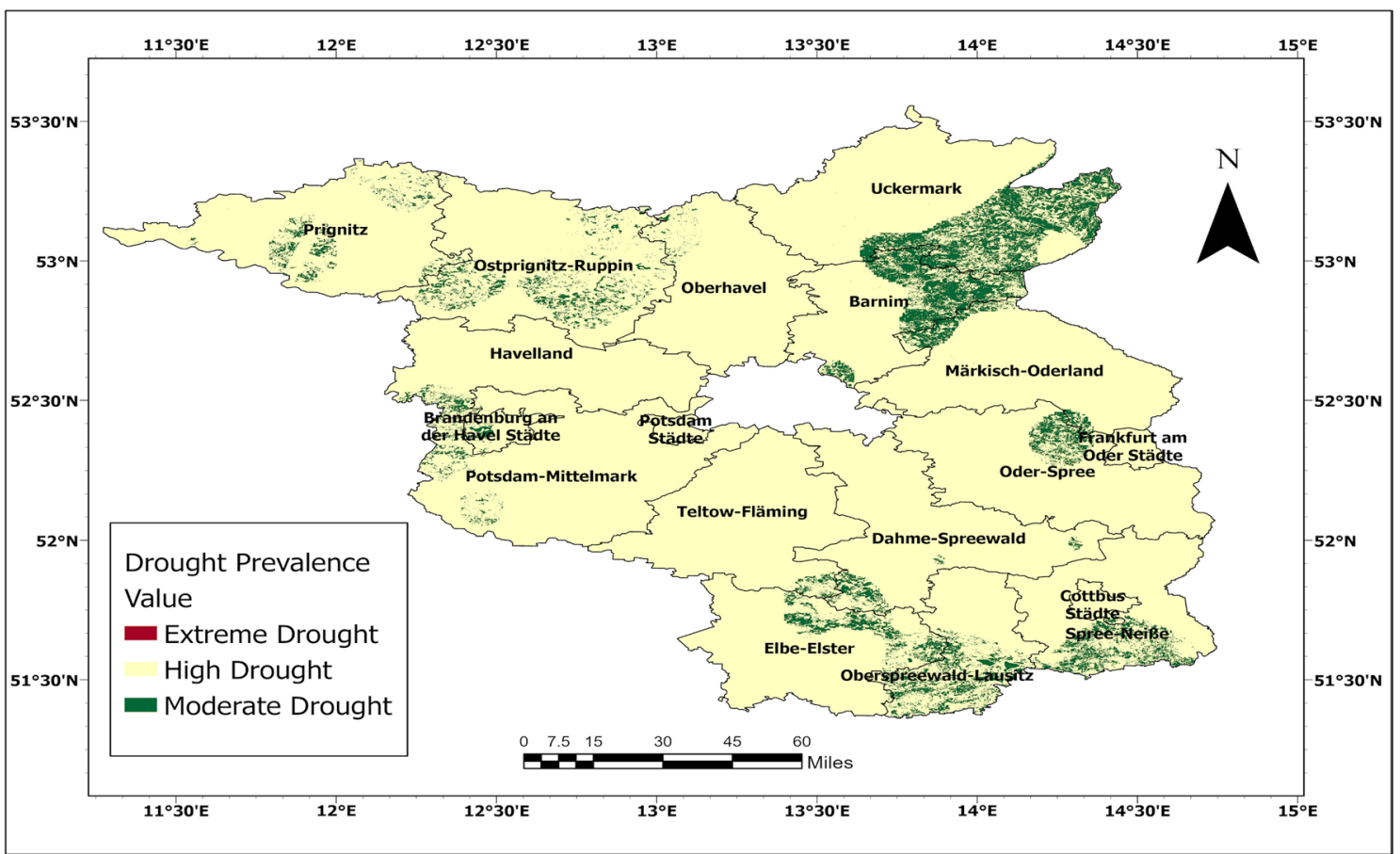

Fig. 12 Drought prevalence in Brandenburg in 2018

Table 3 Drought Prevalence in Brandenburg in 2018

\begin{tabular}{llc}
\hline Drought prevalence & Area $(\mathrm{SqKm})$ & Percentage \\
\hline Extreme drought & 0.19 & 1 \\
High drought & $27,093.05$ & 91 \\
Moderate drought & 2384.96 & 8 \\
Total & 29,478 & 100 \\
\hline
\end{tabular}

Source: authors analysis

Table 4 Summary of drought classes identified at the district level

\begin{tabular}{ll}
\hline Degree of drought & Districts \\
\hline High drought & $\begin{array}{c}\text { Teltow-Fläming, Märkisch-Oderland, Ober- } \\
\text { havel, Dahme-Spreewald, Potsdam Städte, } \\
\text { Havelland, Cottbus Städte, Frankfurt am } \\
\text { Oder Städte }\end{array}$ \\
$\begin{array}{l}\text { High drought with a } \\
\begin{array}{l}\text { little proportion of } \\
\text { moderate drought }\end{array}\end{array}$ & $\begin{array}{l}\text { Märkisch-Oderland, Prignitz, Brandenburg } \\
\text { an der Havel, Potsdam- Mittekmark, Elbe- } \\
\text { Elster, Spree-Neiße, }\end{array}$ \\
$\begin{array}{l}\text { Moderate drought } \\
\text { with a little } \\
\text { proportion of high } \\
\text { drought }\end{array}$ & \\
\hline
\end{tabular}

Source: authors analysis witnessed the greatest economic loss in Germany as a result of the 2018 drought. These findings complement our results from the 'PLAN' model.

The implication is quite obvious: drought models that incorporate multi-criteria and flexibility (such as 'PLAN' model) should be employed in drought assessment against the use of a single and rigid parameter. The flexibility is relevant to tailor studies to suit local peculiarities as was also championed by Mishra and Singh (2011). Also, more attention needs to be given to the agricultural sector in regards to early warning, adaptive planning, and management, relief funds allocation. Drought management strategies especially relief funds disbursement should be done following the drought risk and impact profile in the study area and within Germany. This is because agricultural areas within places highly affected by droughts suffer more losses than urban areas within the same region. Furthermore, agricultural areas, such as Brandenburg, serves provisioning functions in terms of food supplies within and beyond Germany. We also argued for the inclusion of adaptive drought management in the disaster risk management plans of the region.

This study is limited in scope as it does not cover some key aspects of droughts (such as socio-economy) in the region. Hence, we propose future research to investigate the socio-economic impacts of the 2018 droughts on Brandenburg farmers. Research should be done to examine the 
Fig. 13 Agricultural area highly affected by high drought

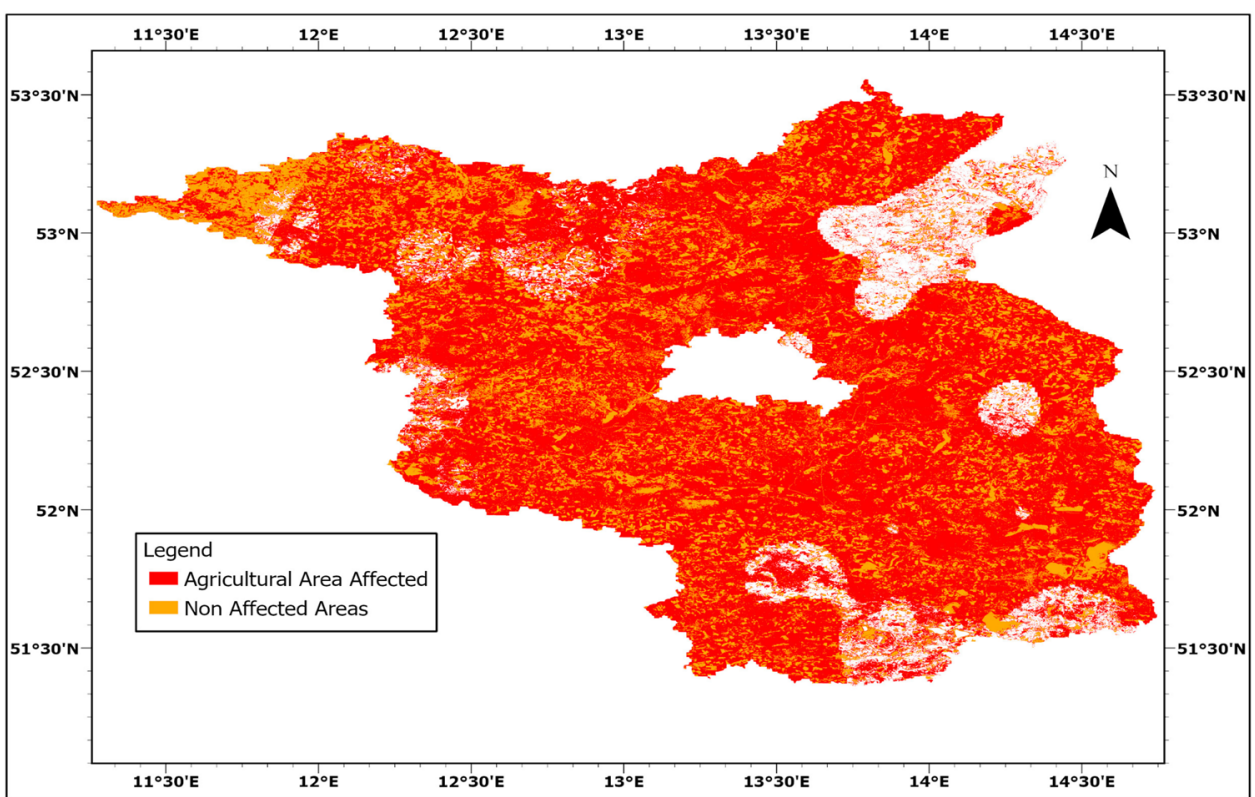

Table 5 Indicating the grouping by agricultural and non-agricultural land use and their respective area cover in $\mathrm{Sq} \mathrm{Km}$

\begin{tabular}{lll}
\hline Reclassified LULC & Area $(\mathrm{Sq} \mathrm{Km})$ & Percentage (\%) \\
\hline Agricultural area (vegetation) & 21.60837 & 73 \\
Non-agricultural area & 7869.63 & 27 \\
Total & 29,478 & 100 \\
\hline
\end{tabular}

Source: authors analysis

Table 6 Agriculture and high drought in Brandenburg

Total agricultural lands ( $\mathrm{Sq} \mathrm{Km})$ $21,608.37$

Agricultural lands impacted by high drought (SqKm) $16,756.06$ Percentage of Agric areas impacted by high drought $77.54 \%$

Source: authors analysis

effectiveness of the drought relief funds (by the German government in 2018) in cushioning the effects of the 2018 drought. Importantly, research should be done to answer the questions: "Have droughts been effectively managed in Brandenburg lately? How? How can we adapt to droughts in Brandenburg under fluctuating climatic conditions?".

\section{Conclusion}

Droughts are characterized by complex interrelationships and therefore, like nature, can only be treated in a modelling fashion. This study has been able to model the incidence of the 2018 drought in Brandenburg (using 'PLAN' model) and has identified districts with high drought risk. This is very relevant to be able to better inform agriculture and thus society and ecosystems in the future and to constantly drive forward adaptation to climate change. The presented results are encouraged to be applied in policymaking and law formulation to be able to support the affected people and districts. Based on our findings, we strongly recommend that 'PLAN' model is adopted in future drought studies while integrating a multi-criteria approach and flexibility based on study context. We also suggest that adaptive drought management is included in the disaster management plans: this is important as the climate is constantly changing and this would help to enable flexibility to capture future uncertainties in climate conditions (Werners et al. 2021). A proactive early warning system should be enforced and encouraged. This would ensure people get prepared and take preventing measures before drought strikes. Drought relief funds should be disbursed with the use of weather and drought impact maps for a better representation of those (farmers) severely affected by drought (as highlighted in the relationship between drought and agricultural land use in our analysis). It is very important that drought research in the study area is demand-based and continuously funded by the government. This would help the public stay informed before and after drought events. In the face of the current climate projections, buildings, agriculture and infrastructures should be designed/planned in a way that is drought resistant. This would help reduce losses from drought. Effective and adaptive implementation of these measures would go a long way in preventing and managing future drought events in the study area. 
Funding Open Access funding enabled and organized by Projekt DEAL.

\section{Declarations}

Conflict of interest The authors declare that they have no conflict of interest.

Open Access This article is licensed under a Creative Commons Attribution 4.0 International License, which permits use, sharing, adaptation, distribution and reproduction in any medium or format, as long as you give appropriate credit to the original author(s) and the source, provide a link to the Creative Commons licence, and indicate if changes were made. The images or other third party material in this article are included in the article's Creative Commons licence, unless indicated otherwise in a credit line to the material. If material is not included in the article's Creative Commons licence and your intended use is not permitted by statutory regulation or exceeds the permitted use, you will need to obtain permission directly from the copyright holder. To view a copy of this licence, visit http://creativecommons.org/licenses/by/4.0/.

\section{References}

Agboola AM, Ayanlade A (2016) sea level rise and its potential impacts on coastal urban area: a case of Eti-osa, Nigeria. Analele Universităţiidin Oradea, Seria Geografie 188-200. http://geografieu oradea.ro/Reviste/Anale/Art/2016-2/9.AUOG_715_Ayansina.pdf.

Benedetti R, Rossini P (1993) On the use of NDVI profiles as a tool for agricultural statistics: The case study of wheat yield estimate and forecast in Emilia Romagna. Remote Sens Environ 45(3):311326. https://doi.org/10.1016/0034-4257(93)90113-C

Berhail S, Tourki M, Merrouche I, Bendekiche H (2021) Geo-statistical assessment of meteorological drought in the context of climate change: case of the Macta basin (Northwest of Algeria). Model Earth Syst Environ. https://doi.org/10.1007/s40808-020-01055-7

Bhuiyan C, Singh RP, Kogan FN (2006) Monitoring drought dynamics in the Aravalli region (India) using different indices based on ground and remote sensing data. Int J Appl Earth Obs Geoinf 8(4):289-302. https://doi.org/10.1016/j.jag.2006.03.002

Bloch R, Wechsung F, Hess J, Bachinger J (2015) Climate change impacts of legume-grass swards: implications for organic farming in the Federal State of Brandenburg. Germany. Reg Environ Change 15(2):405-414. https://doi.org/10.1007/ s10113-014-0656-2

Brito MM, Kuhlicke C, Marx A (2020) Near-real-time drought impact assessment: a text mining approach on the 2018/19 drought in Germany. Environ Res Lett 15:1-11. https://doi.org/10.1088/ 1748-9326/aba4ca

Buras A, Rammig A, Zang CS (2020) Quantifying impacts of the 2018 drought on European ecosystems in comparison to 2003. Biogeosciences 17(6):1655-1672. https://doi.org/10.5194/ bg-17-1655-2020

Cancelliere A, Mauro GD, Bonaccorso B, Rossi G (2007) Drought forecasting using the standardized precipitation index. Water Resour Manage 21:801-819. https://doi.org/10.1007/s11269-006-9062-y

Deutscher Wetterdienst (2020) Local weather and climate data of Berlin and Brandenburg. https://www.dwd.de/EN/weather/weather climate_local/berlin-brandenburg/bbb_node.html. Accessed 15 February 2021.

Deutscher Wetterdienst (2021) Climate and drought index. https:// www.dwd.de/DE/leistungen/rccem/int/rcccm_int_spi.html, updated on 2021. Accessed 5 March 2021.
Erfurt M, Glaser R, Blauhut V (2019) Changing impacts and societal responses to drought in southwestern Germany since 1800. Reg Environ Change 19(8):2311-2323. https://doi.org/10.1007/ s10113-019-01522-7

FAO (2019) Proactive approaches to drought preparedness - where are we now and where do we go from here? Rome. http://www.fao. org/3/ca5794en/ca5794en.pdf.

Gutzler C, Helming K, Balla D, Dannowski R, Deumlich D, Glemnitz (2015) Agricultural land use changes: a scenario-based sustainability impact assessment for Brandenburg, Germany. Ecol Indic 48:505-517. https://doi.org/10.1016/j.ecolind.2014.09.004

Helmholtz Institut (2020) Drought monitor Germany. https://www.ufz. de/index.php?en=37937. Accessed 10 January 2021.

Holsten A, Vetter T, Vohland K, Krysanova V (2009) Impact of climate change on soil moisture dynamics in Brandenburg with a focus on nature conservation areas. Ecol Model 220(17):2076-2087. https://doi.org/10.1016/j.ecolmodel.2009.04.038

IPCC (2019): Impacts of $1.5^{\circ} \mathrm{C}$ of global warming on natural and human systems. https://www.ipcc.ch/site/assets/uploads/sites/2/ 2019/02/SR15_Chapter3_Low_Res.pdf. Accessed 15 February 2021

Karlsruhe Institute of Technology (KIT) (2018) Drought affected about 90\% of the German Territory. Germany. Sandra Wiebe. https:// www.kit.edu/kit/english/pi_2018_102_drought-affected-about-90of-the-german-territory.php. Accessed 15 February 2021.

Karnieli A, Dall'Olmo G (2003) Remote-sensing monitoring of desertification, phenology, and droughts. Manage Environ Qual 14(1):22-38. https://doi.org/10.1108/14777830310460360

Kathleen Kipping (2020) Climate change-regional vulnerability analysis for the Federal State of Brandenburg. A sector-specific perception of adaptation strategies and action recommendations. Universitaet Potsdam. https://www.uni-potsdam.de/fileadmin/ projects/geographie/Regionalwissenschaft/Projekte/Climate_ Change_-_Regional_Vulnerability_Analysis_for_the_Federak State_of_Brandenburg.pdf. Accessed 15 February 2021

Kim T, Valdes JB (2003) Nonlinear model for drought forecasting based on a conjunction of wavelet transforms and neural networks. J Hydrol Eng ASCE 8(6):319-328. https://doi.org/10. 1061/(ASCE)1084-0699(2003)8:6(319)

Malik A, Abdalla R (2016) Geospatial modeling of the impact of sea level rise on coastal communities: application of Richmond, British Columbia, Canada. Model Earth Syst Environ 2(3):1-17. https://doi.org/10.1007/s40808-016-0199-2

Mishra AK, Desai VR (2006) Drought forecasting using feed forward recursive neural network. Int J Ecol Model 198(1):127-138. https://doi.org/10.1016/j.ecolmodel.2006.04.017

Mishra AK, Desai VR, Singh VP (2007) Drought forecasting using a hybrid stochastic and neural network model. J Hydrol Eng ASCE 12(6):626-638. https://doi.org/10.1061/(ASCE)1084-0699(2007) 12:6(626)

Mishra AK, Singh VP (2011) Drought modelling-a review. J Hydrol 403:157-175. https://doi.org/10.1016/j.jhydrol.2011.03.049

Morid S, Smakhtin V, Bagherzadeh K (2007) Drought forecasting using artificial neural networks and time series of drought indices. Int J Climatol 27(15):2103-2111. https://doi.org/10.1002/joc.1498

Moulin S, Bondeau A, Delecolle R (1998) Combining agricultural crop models and satellite observations: from field to regional scales. Int J Remote Sens 19(6):1021-1036. https://doi.org/10.1080/01431 1698215586

Murthy CS, Laxman B, Sesha Sai MVR (2015) Geospatial analysis of agricultural drought vulnerability using a composite index based on exposure, sensitivity and adaptive capacity. Int J Disaster Risk Reduct 12:163-171. https://doi.org/10.1016/j.ijdrr.2015.01.004

Muthumanickam D, Kannan P, Kumaraperumal R, Natarajan S, Sivasamy R, Poongodi C (2011) Drought assessment and monitoring through remote sensing and GIS in western tracts of Tamil 
Nadu, India. Int J Remote Sens 32(18):5157-5176. https://doi.org/ $10.1080 / 01431161.2010 .494642$

Njoku CG, Efiong J, Uzoezie AC, Okeniyi FO, Alagbe AO (2018) A GIS multi-criteria evaluation for flood risk-vulnerability mapping of Ikom local government area, cross river state. J Geogr Environ Earth Sci Int 15(2):1-17

Olaseeni OG, Oladapo MI, Olayanju GM (2021) Vulnerability assessment of an aquifer in the basement complex terrain of Nigeria using 'LAHBUD' model. Model Earth Syst Environ 7:833-852. https://doi.org/10.1007/s40808-020-00912-9

Reinermann S, Gessner U, Asam S, Kuenzer C, Dech S (2019) The effect of droughts on vegetation condition in germany: an analysis based on two decades of satellite earth observation time series and crop yield statistics. Remote Sensing 11(15):1-17. https://doi.org/ $10.3390 /$ rs 11151783

Reyer C, Bachinger J, Bloch R, Hattermann FF, Ibisch PL, Kreft S et al (2012) Climate change adaptation and sustainable regional development: a case study for the Federal State of Brandenburg, Germany. Reg Environ Change 12(3):523-542. https://doi.org/10. 1007/s10113-011-0269-y

Rouse JR, Haas J, Schell DD, Harlan J (1974) Monitoring the vernal advancement and retrogradation (greenwave effect) of natural vegetation. Texas, USA

Saaty TL (1980) The analytic hierarchy process. McGraw-Hill, New York

Schindler U, Steidl J, Müller L, Eulenstein F, Thiere J (2007) Drought risk to agricultural land in Northeast and Central Germany. J Plant Nutr Soil Sci 170(3):357-362. https://doi.org/10.1002/jpln.20062 2045
Sobrino JA, Jiménez-Muñoz JC, Paolini L (2004) Land surface temperature retrieval from LANDSAT TM 5. Remote Sens Environ 90(4):434-440. https://doi.org/10.1016/j.rse.2004.02.003

Troegel T, Schulz C (2018) Ergebnisse der Agrarstrukturerhebung 2016 für das Land Brandenburg. Zeitschrift Für Amtliche Statistik. https://www.statistik-berlin-brand-enburg.de/publikationen/ aufsaetze/2018/HZ_201801-08.pdf. Accessed 15 February 2021.

Werners SE, Wise RM, Butler JRA, Totin E, Vincent K (2021) Adaptation pathways: a review of approaches and a learning framework. Environ Sci Policy 116:266-275. https://doi.org/10.1016/j.envsci. 2020.11.003

Wolff S, Hüttel S, Nendel C, Lakes T (2021) Agricultural landscapes in Brandenburg, Germany: an analysis of characteristics and spatial patterns. Int J Environ Res. https://doi.org/10.1007/ s41742-021-00328-y

World Data (2021): Climate of Brandenburg. WorldData. https:// www.worlddata.info/europe/germany/climate-brandenburg.php. Accessed 15 February 2021.

Yisehak B, Zenebe A (2021) Modeling multivariate standardized drought index based on the drought information from precipitation and runoff: a case study of Hare watershed of Southern Ethiopian Rift Valley Basin. Model Earth Syst Environ 7:1005-1017. https:// doi.org/10.1007/s40808-020-00923-6

Publisher's Note Springer Nature remains neutral with regard to jurisdictional claims in published maps and institutional affiliations. 